담관 침범을 동반한 저혈관성 간세포암종에서 경동맥화학색전술, 정위 체부 방사선 치료, sorafenib을 병합하여 부분관해를 경험한 1예

동남권 원자력 의학원 내과 ${ }^{1}$, 영상의학과 ${ }^{2}$, 방사선 종양학과 ${ }^{3}$

황상연 $^{1} \cdot$ 이선미 ${ }^{1} \cdot$ 임정우 $^{1} \cdot$ 김준석 $^{1} \cdot$ 안상부 $^{2} \cdot$ 지은경 $^{2} \cdot$ 최철원 $^{3} \cdot$ 양광모 $^{3}$

\title{
A Case of Hypovascular Hepatocellular Carcinoma Invading Bile Duct with Partial Remission with Combination Therapy of Transarterial Che- moembolization and Stereotactic Body Radiation Therapy and Sorafenib
}

Sang Youn Hwang', Seon-Mi Lee', Jung Woo $\mathrm{Im}^{1}$, Joon Suk Kim¹, Sang Bu Ahn², Eun Kyeong Ji², Chul Won Choi', Gwang-Mo Yang ${ }^{3}$

Departments of ${ }^{1}$ Internal Medicine and Gastrointestinal Cancer Center, ${ }^{2}$ Radiology and ${ }^{3}$ Radiation Oncology, Dongnam Institute of Radiological and Medical Sciences, Busan, Korea

Received Sep. 10, 2013

Revised Sep. 13, 2013

Accepted Sep. 15, 2013
Hepatocellular carcinoma (HCC) patients with bile duct invasion have a poor prognosis because many do not receive effective treatment. Surgical resection is thought to be only option of curative treatment, increasing chance of survival, but it is possible to minor group of patients because of poor reserved liver function associated with underlying liver disease and obstructive jaundice. Therefore many clinicians or centers still select locoregional therapy such as transarterial chemoembolization (TACE), radiation therapy (RT) etc. Stereotactic body radiation therapy (SBRT) is new technology providing very highly conformal ablative radiation dose for a small numbers (1-5 fractions) of large fraction size and is expected to salvage modality for HCC showed incomplete response of TACE due to vascularity or accessibility of feeding artery. Based on above suggestions, we herein offer our experience of a patient with partial remission of tumor by combination therapy of TACE, SBRT and sorafenib. Further study, maybe regarding a combination of locoregional and systemic therapy (so called multidisciplinary approach), is necessary on how to manage HCC patients with bile duct invasion or sparse vascularity. (Journal of The Korean Liver Cancer Study Group 2013;13:178-184)

Keywords: Hypovascular hepatocellular carcinoma; Bile duct invasion; Trasnarterial chemoembolization; Stereotactic body radiation therapy

\section{Corresponding author: Sang Youn Hwang}

Department of Internal Medicine, Gastrointestinal Cancer Center, Dongnam Institute of Radiological \& Medical Sciences, 40 Jwadong-gil, Jangan-eup, Busan 619-953, Korea

Tel. +82-51-720-5114, Fax. +82-51-720-5992

E-mail:mongmani@daum.net
서 론

간세포암종의 담관 침범은 그 유병율이 0.8-12.9\%로 상대적으로 드문것으로 보고되고 있지만 담즙 정체 및 간기능 저하를 유발하여 환자의 예후를 불량하게 하는 것으로 알려져 있다. ${ }^{1}$ 현재까지는 침범된 담관 및 간내 암에 대한 수술적 절제가 유일한 완치의 기회로 생각되 
지만 이러한 환자군에서 수술을 통한 예후 개선 효과에 대해서는 이견이 있는 상황이며 외과적 수술의 적응이 될 정도로 간기능이 유지되어 있는 경우 또한 많지 않기 에 실제 임상에서는 여전히 국소치료 혹은 전신치료를 하고 있는 실정이며 선택된 환자에서 치료 후에 암의 관 해 혹은 안정화를 경험하기도 한다. 저자들은 위의 배 경에 맞춰 담관 침범을 동반한 저혈관성 간세포암종에 서 경동맥화학색전술, 정위 체부 방사선 치료, sorafenib 을 병합하여 부분관해를 경험하여 간기능을 정상으로 유지한 증례를 경험하였기에 이를 보고하는 바이다.

\section{증 례}

\section{1. 임상소견}

상기 53 세 남자 환자는 특이 병력 없던 분으로 내원 1 개월 전부터 체중감소가 발생하여 개인의원에서 시행 한 복부초음파에서 간우엽에 다발성 간종괴가 관찰되 어 본원으로 전원되었다. 음주력, 흡연력, 가족력상 특 이 소견이 없었다. 문진소견에서 경미한 복부 불편감이 있었다. 이학적 검사에서 공막의 황달 소견은 없었으며 복부는 편평하고 부드러웠다. 복부에 압통과 반발통은 없었고 간이나 비장은 촉지되지 않았다. 내원 당시 시
행한 일반혈액검사상 백혈구 $6,800 / \mu \mathrm{L}$, 혈색소 $13.4 \mathrm{~g} /$ $\mathrm{dL}$, 혈소판 $350,000 / \mu \mathrm{L}$ 이었다. 일반화학검사상 total protein $7.5 \mathrm{~g} / \mathrm{dL}$, albumin $3.7 \mathrm{~g} / \mathrm{dL}$, AST/ALT 46/36 IU/ $\mathrm{L}$, total bilirubin $0.3 \mathrm{mg} / \mathrm{dL}$, alkaline phosphatase 163 $\mathrm{IU} / \mathrm{L}$, gamma-GT $95 \mathrm{IU} / \mathrm{L}$ 이었다. 혈액응고검사상 PT $88 \%$ 였으며 종양표지자검사상 AFP $8.93 \mathrm{ng} / \mathrm{mL}$, PIVKA $856 \mathrm{mAU} / \mathrm{mL}$ 이었고, 바이러스간염표지자 검사상 $\mathrm{HB}-$ sAg (+), HBeAg (-), anti-HBe (+), HBV DNA 105 IU, anti-HCV (-)이었다.

\section{2. 영상 및 병리 소견}

복부 전산화단층촬영에서 $\mathrm{S} 6 / 7$ 에 $12 \times 9 \mathrm{~cm}$ 크기의 경 계가 명료한 팽창결절형의 종괴가 관찰되었고, $\mathrm{S} 5 / 8$ 에 장경합이 $9 \mathrm{~cm}$ 인 dumbbell shape의 결절형 종괴가 관 찰되었고, 그 외 직경 $1 \mathrm{~cm}$ 내외의 종괴가 3-4개 정도 관 찰되었다. 이들 종괴 모두는 동맥기에 조영증강 및 문 맥기에 조기배출을 보여 다발성 간세포암종에 합당한 소견을 보였다(Fig. 1A, 1B). Liver MRI diffusion weight image에서 고신호 강도를 보였고(Fig. 2A), 양전자방출 단층촬영에서는 큰 두 종괴 모두에서 섭취 증가가 관찰 되었다(Fig. 3A).
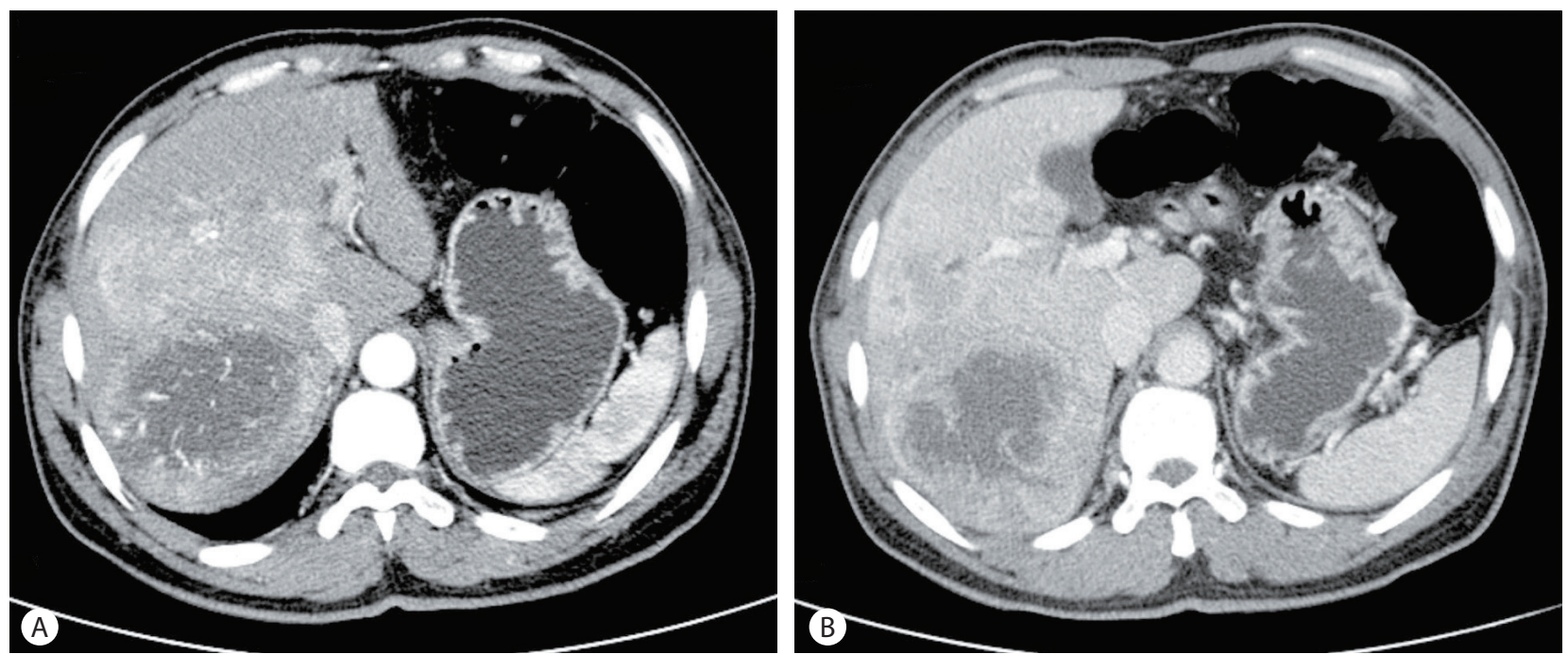

Figure 1. Abdominal CT during arterial (A) and portal (B) phase. A $12 \mathrm{~cm}$ sized hepatic mass with central necrosis and $9 \mathrm{~cm}$ sized dumbbell shaped mass lesions with early wash-out of contrast were noted in the right lobe. 

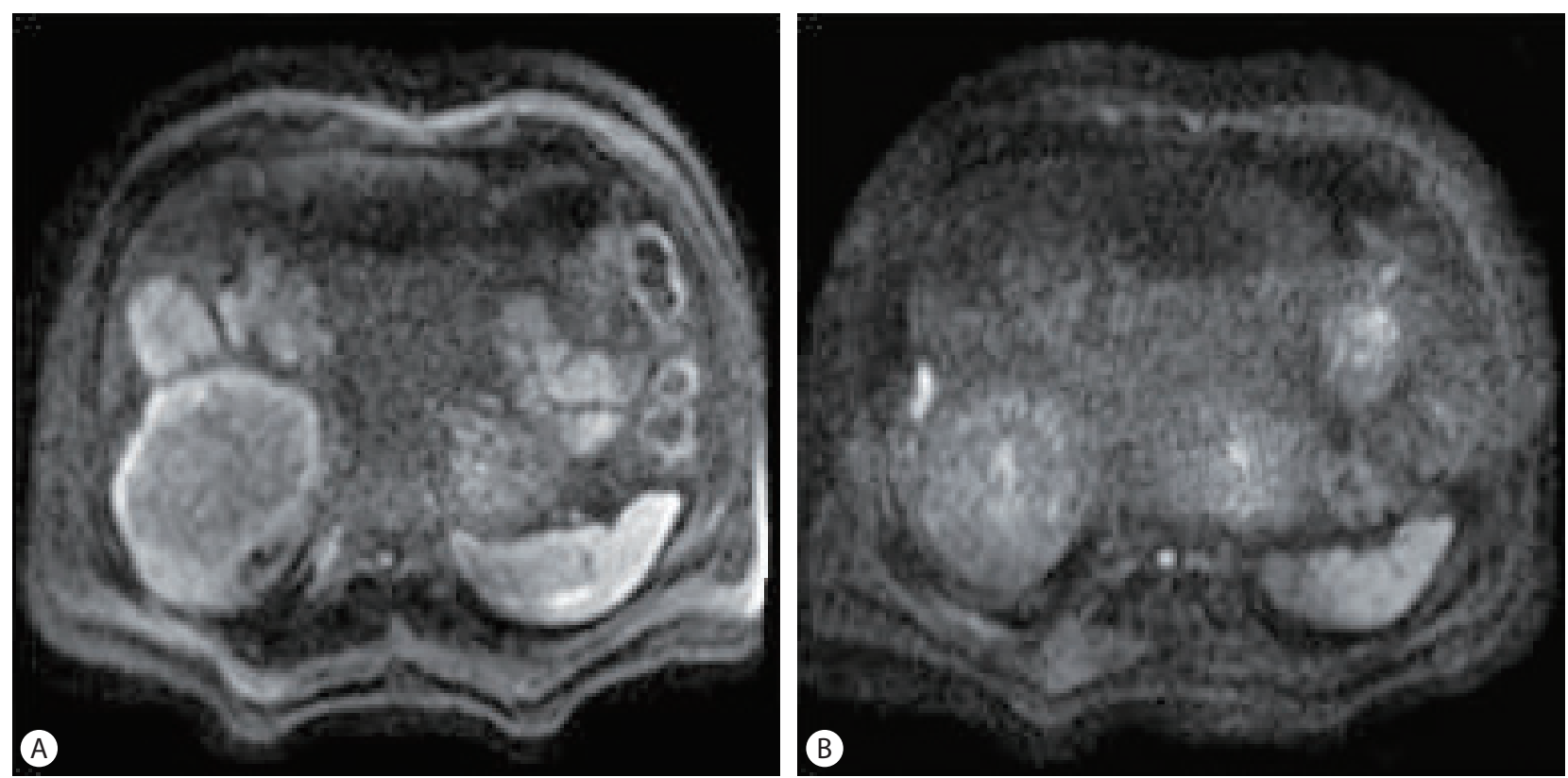

Figure 2. Liver MRI with T2 diffusion weighted images. (A) Initial finding. One huge mass and dumbbell shaped mass with diffusion restriction were noted. (B) Final finding. Shrunken mass without diffusion restriction were noted.
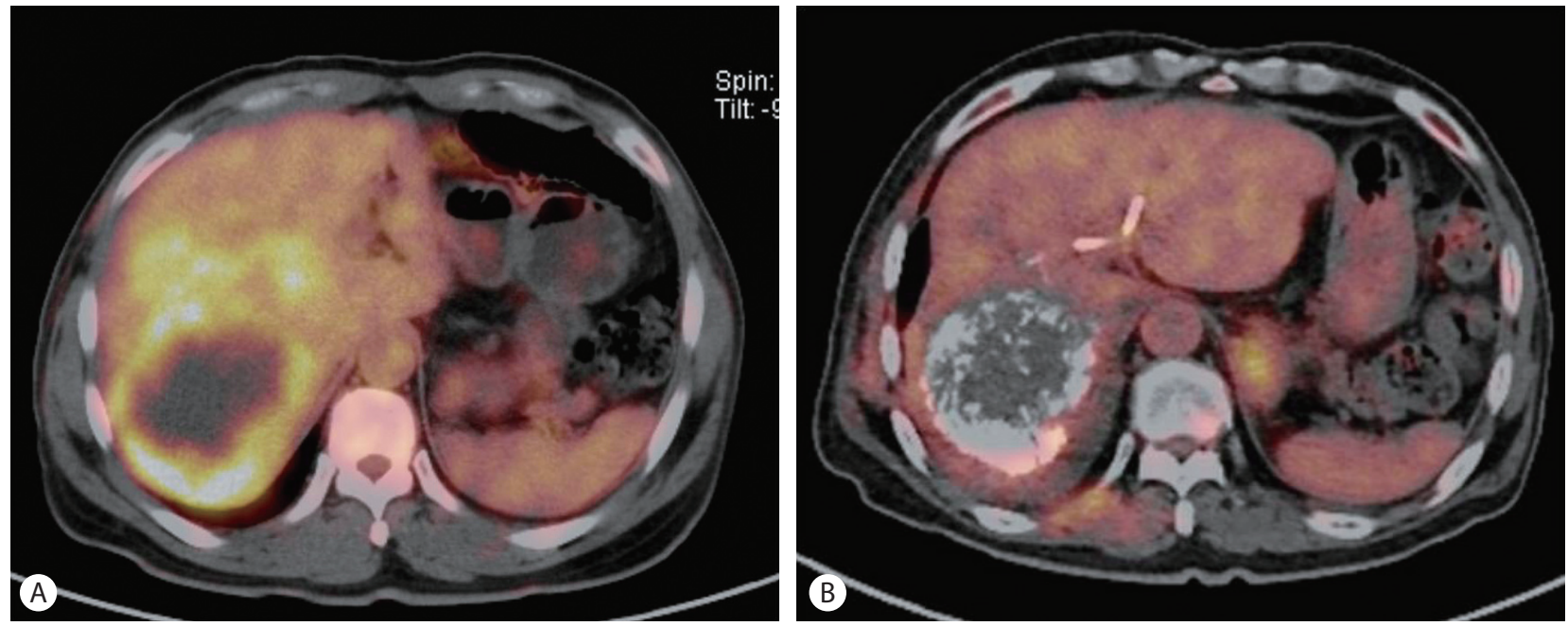

Figure 3. PET-CT scan. (A) Initial finding. Several abnormal uptakes of fludeoxyglucose (FDG) were noted in right hepatic lobe. (B) Final finding. Previous abnormal uptakes of FDG disappeared.

\section{3. 진단 및 치료경과}

상승된 종양 표지자와 영상소견에 의해 Child-Pugh $\mathrm{A}$ 등급, 간세포암(modified UICC stage III)으로 진단하 였고, 큰 두 종괴 주위에 경한 다발성 담관 확장이 관찰 되어 담관 침범이 의심되는 상황이었다. 수술(extended right hemihepatectomy)을 고려해보기도 하였으나 진단 당시 간좌엽에도 small HCC가 의심되는 상황이었고 간
좌엽이 크지 않아 국소치료를 시행하기로 결정하였다. 2 회의 경동맥화학색전술(Fig. 4) 후 시행한 lipiodol CT 상 S5/8의 종괴에는 partial uptake만 있고 조영증강이 되지 않는 중심부 저음영 부위는 여전히 관찰되었고 (Fig. 5), 이 종괴 전체는 liver MRI, T2 diffusion weighted image에서 high signal로 관찰되어 combined cholangiocarcinoma의 가능성 염두하에 2012년 2월 27일 조영 증강 초음파 유도하에 vascularity가 없는 중심부에서 
조직검사를 시행하였고(Fig. 6A, 6B), 간세포암으로 증 명되었다. 이 부위에 대해서 색전술로 더 이상의 추가 이득을 볼 수 없다고 판단되었고, 크기와 담관 침범으 로 인해 고주파열치료가 불가능할 것으로 생각되어 2012년 3월 16일-2012년 3월 22에 51 Gray를 3회로 분 할하여 정위 체부 방사선치료를 시행하였다(Fig. 7). 이 후 2012년 4월 23일 추적 CT상 이전에 반응이 없던 S5/8 종괴의 크기가 감소하기 시작하였고 2012년 4월 24일 에 경험적 색전술을 시행하였으나 additional lipiodol uptake가 되는 곳은 관찰되지 않았다. 2012년 6월 26일 MRI상 S6에 new HCC 관찰되어 2012년 7월 2일 4번째

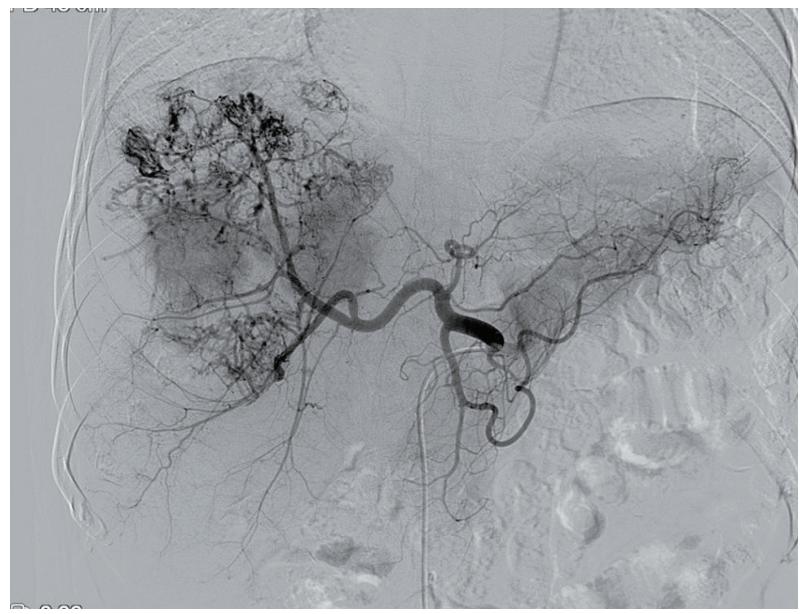

Figure 4. Hepatic angiogram. Huge strong hypervascular hepatic mass was noted in the right lobe. Tumor staining of dumbbell shaped mass was vague.
색전술을 시행하였고, 5일후 색전술 시행부위의 간농 양과 함께 septic shock이 발생하여 경피적배액술 시행 후 호전되었다. 2012년 10월 시행한 MRI와 PET-CT상 hepatic dome과 S5에 partial enhancement를 보이는 multiple HCC lesion이 관찰되고 2012년 10월 26일 5번 째 색전술을 시행하였다. 이 후 시행한 lipiodol CT상 partial uptake가 관찰되었고 증상과 생화학 검사에서 이상은 없었으나 이전 방사선치료를 시행한 S5/8 lesion 은 계속 크기가 감소하였으나 우측 간내담관 근처의 hypovascular residual mass가 간문부 담관으로 침범하 고 있는 소견이 관찰(Fig. 8)되어 2013년 1월 25일부터

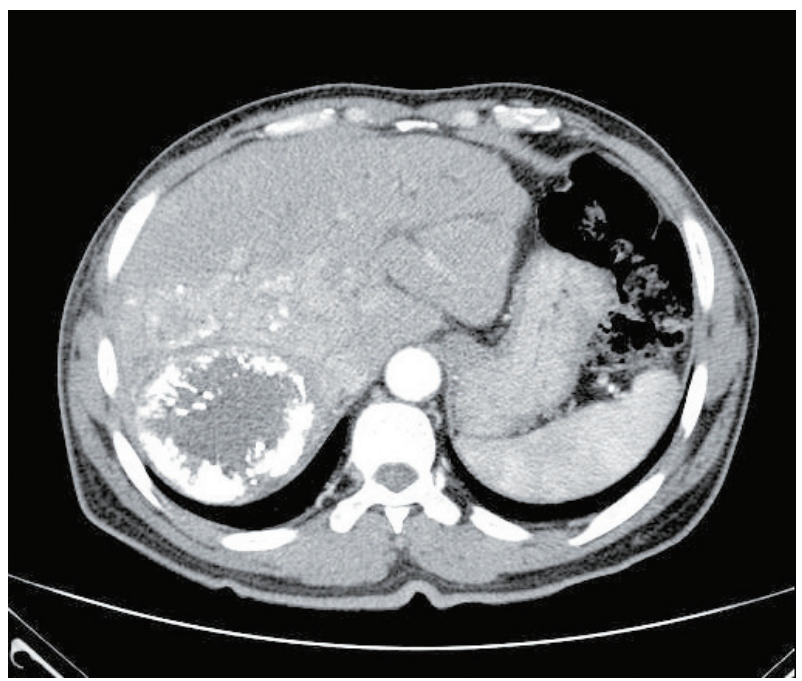

Figure 5. Abdominal CT after second TACE. Sparse lipiodol uptake in dumbbell shaped mass was noted.

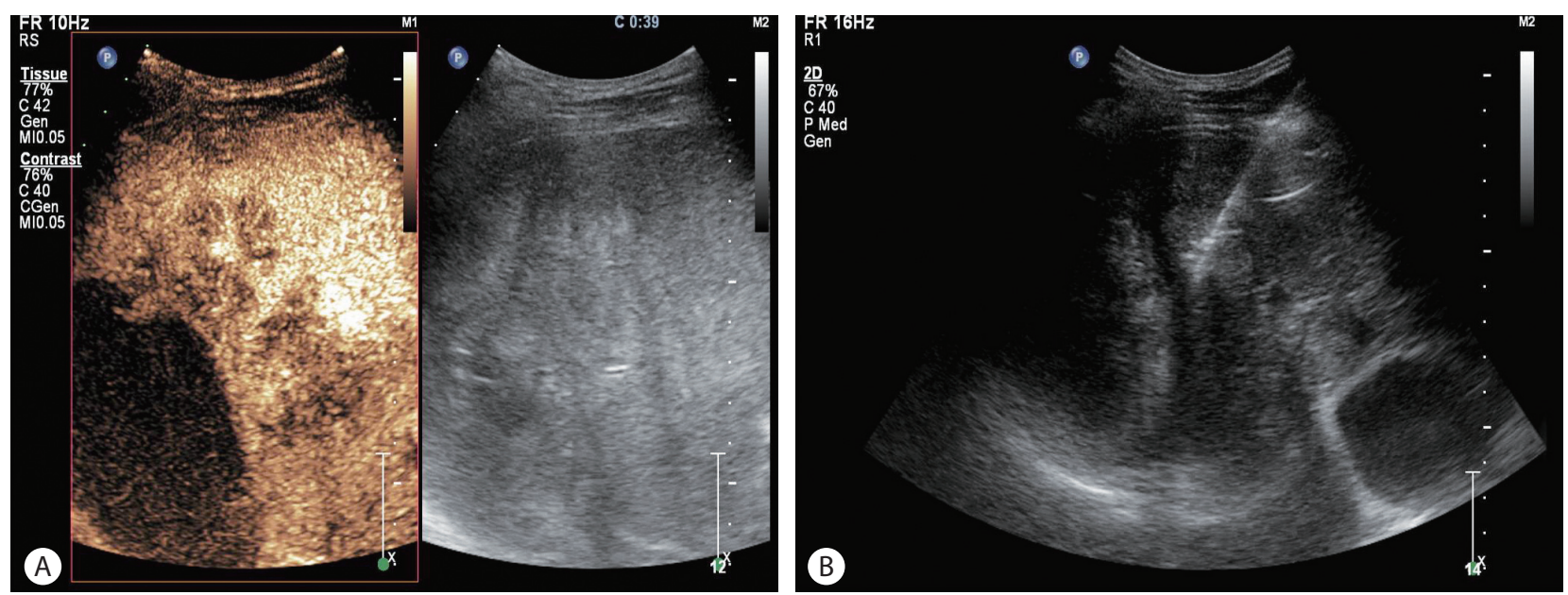

Figure 6. (A) Contrast enhanced ultrasonography finding. Two hypoechoic and hypovascular masses were noted. (B) Needle biopsy was performed in center of mass. 


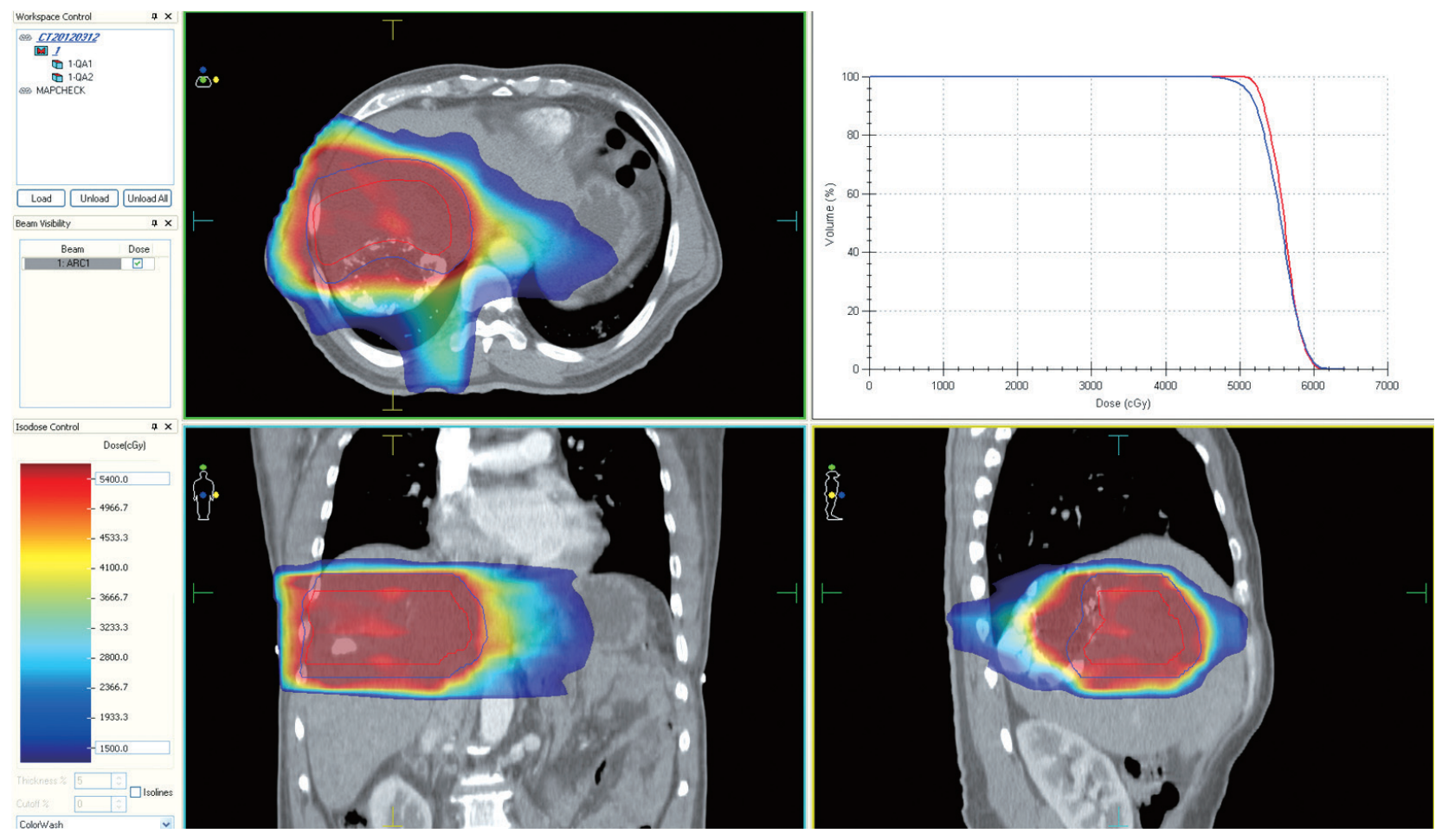

Figure 7. Simulation and planning image of stereotactic body radiation therapy.
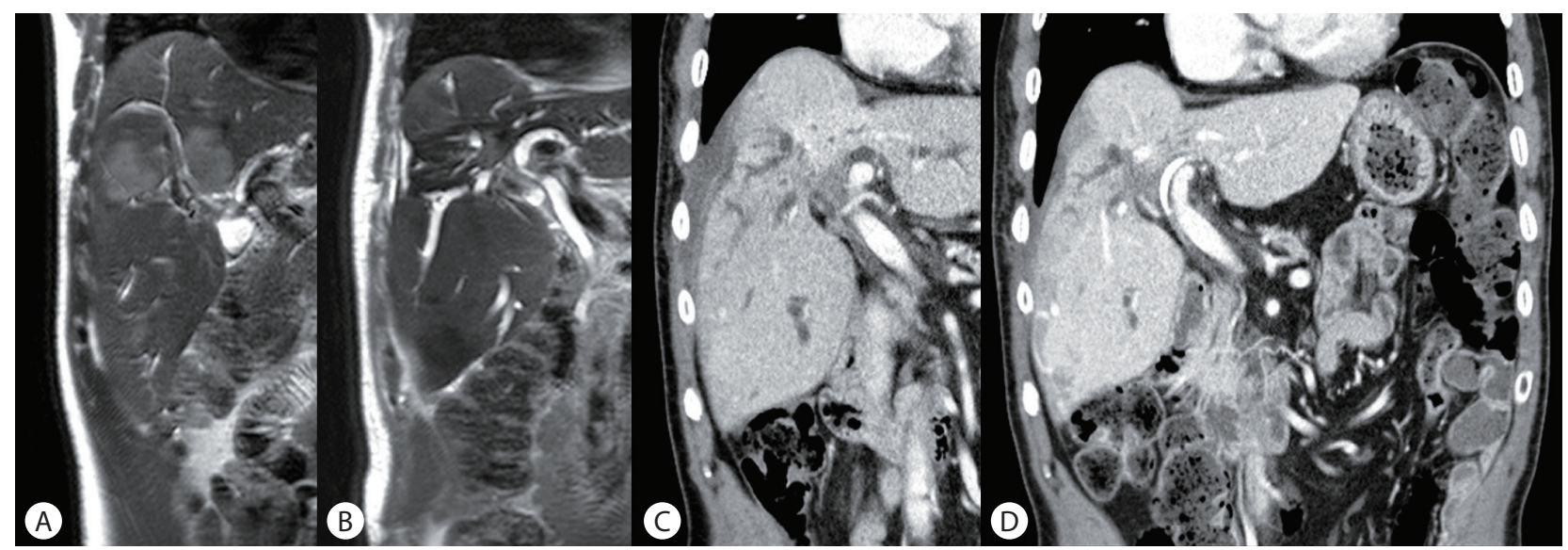

Figure 8. Serial MRI findings of dumbbell shaped mass with involvement of right intrahepatic duct. (A) Initial finding. (B) Previous dumbbell shaped mass was nearly disappeared, but involvement of right intrahepatic duct by mariginal recurred mass was noted. (C) Invasion of bile duct was extended to left main intrahepatic duct. (D) Stable disease was noted after biliary drainage and use of sorafenib.

sorafenib 투여를 시작하였으나 hand foot skin reaction 으로 감량과 중단을 반복하던 중 2013년 3월 12일에 우 상복부 통증과 황달을 주소로 시행한 CT상 이전 종양 이 좌측간내담관으로 침범하여 담관 확장이 심화된 양 상이어서 경피적 담관 배액술을 시행하였고 이 후 sorafenib full dose로 증량하여 투약을 유지한 지 2주째 시행한 MRI와 PET-CT상 간내암은 완전관해의 소견을
보였고, 종양표지자 검사도 정상이었다(Figs. 2B, 3B). Sorafenib을 full dose 증량한지 5주째 시행한 CT상 종양 의 범위는 이전과 변함이 없었고 증상과 생화학적 검사 상 이상 소견이 관찰되지 않았다. 환자는 현재 경피적 담관 배액을 유지한 상태에서 sorafenib 투여하여 경과 관찰 중이며 잔존 간기능도 여전히 Child-Pugh A 등급 으로 유지하고 있다. 


\section{고 찰}

담관 침범을 동반한 간세포암종은 중앙생존기간 2.54.5 개월로 예후가 극히 불량한 것으로 알려져 있고, 현 재까지 정립된 치료지침이 없는 상태이지만 절제 가능 한 상태라면 수술이 유일한 완치의 기회일 수 있을 것으 로 여겨지고 있다. 담관 침범을 동반한 간세포암종에서 수술의 성적은 15-40명 내외의 환자를 대상으로 한 몇 개의 소규모 연구에서만 보고하고 있으며 중앙생존기 간 31 개월, 5 년 생존율을 $50 \%$ 까지 보고한 연구도 있지 만 이는 microscopic bile duct invasion을 포함한 경우이 고 macroscopic bile duct invasion을 동반한 대부분의 다른 연구에서의 중앙생존기간은 11-12개월, 5년 생존 율 28-39\% 였다. 하지만 실제 수술이 가능할 정도로 간 기능이 보존되어 있는 경우가 적고 담관 침범을 동반한 간세포암종의 $30 \%$ 정도에서 문맥침범을 동반하고 있 어 실제 수술적으로 절제가능한 경우는 2-13\% 정도에 불과하다. ${ }^{2-4}$ 따라서 실제 임상에서는 여전히 경동맥화 학색전술 혹은 방사선치료 등의 국소치료를 시행하고 있는 실정이며 2-12명 정도를 대상으로 시행한 한 연구 에서는 중재적 혹은 내시경 시술을 통해 담관 침범에 의 한 황달을 해결하고 색전술 및 방사선 치료를 시행하여 평균 8-13.4개월의 중앙생존기간을 보고하고 있다. ${ }^{5}$ 경 동맥 화학색전술은 근치적 치료가 힘든 다발성 간세포 암종에서 표준치료로 시행되고 있으며 때로 선택된 경 우에서 담관 침범을 동반한 경우에도 영양 혈관을 정확 히 찾아 미세도관을 이용하여 초선택적 색전술을 시행 하여 좋은 종양 치료 반응을 경험하기도 하는 ${ }^{6}$ 반면, 영 양혈관이 간동맥의 근위부에서 가늘게 기시하여 찾기 가 쉽지 않은 경우도 있으며 색전술 후 간경색이나 간농 양 및 담관 폐색을 동반한 담관염 등을 유발될 위험성이 있고 vascularity가 좋지 않을 때에는 색전술 단독으로 종양의 완전괴사를 얻어내기 힘들 수 있다. 최근 색전 술에 다른 국소치료를 병합하여 종양반응율을 높이는 시도가 계속되고 있는데, 그 중 방사선 치료는 다른 국 소치료술(고주파 열치료, 에탄올 주입술 등)로 접근이 힘들거나 종양 괴사가 힘들것으로 생각되는 경우에 유 용한 병합치료로 사용될 수 있다. 최근 방사선 기계 및 조사 기술의 발전을 바탕으로 주위 장기 손상을 최소화
하면서 고용량의 방사선을 3-5회라는 짧은 횟수로 조사 하는 정위 체부 방사선 치료(stereotactic body radiation therapy, SBRT)란 개념이 도입되면서 기존에 저용량의 방사선을 20-25회 정도로 치료하는 것에 비해 방사선생 물학적으로 더 좋은 종양효과를 보일 수 있을 것으로 기 대하고 있고 간세포암종에 대해서도 연구들이 보고되 고 있다. 실제 최근의 국내의 다기관 2상 연구에서 이전 색전술로 불완전한 반응을 보인 47 명의 환자를 대상으 로 간세포암종 부위에 총 용량 42-60 Gray의 방사선을 3 번에 나누어서 조사한 결과 SBRT 종료 6개월 내에 $38.3 \%$ 에서 완전반응, $38.3 \%$ 에서 부분반응을 보였으며 2 년 동안의 국소조절률(완전반응+부분반응+안정화) 이 $94.6 \%, 2$ 년 생존율이 $68.7 \%, 2$ 년 무병생존율이 $33.8 \%$ 인 것으로 보고하였고 특히 총 방사선량이 54 Gray 이상이었던 경우는 2년 국소 조절율이 $100 \%$ 로 보 고하였으며 Grade 4 toxicity는 4.3\%로 보고하여 색전술 에 부분 반응을 보이는 경우 SBRT가 효과적이면서도 안전한 구제요법으로 사용될 수 있음에 대해 제시하였 다. ${ }^{7}$

요컨대 이 증례는 담관 침범을 동반한 다발성 거대 간 세포암종을 경동맥화학색전술로 치료 중 리피오돌 침 착이 되지 않는 저혈관성 종양부위를 조직검사로 확진 한 뒤 정위 체부 방사선 치료를 통해 기존 간세포암종의 완전 관해를 이루었으나 우측 주담관 주위의 간세포암 종이 재발하면서 발생한 담관 침범을 경피적 담도배액 후 sorafenib 사용으로 안정화시킨 증례이다. 따라서 담 관 침범을 동반하거나 저혈관성인 간세포암종에서 기 존 잔존 간기능 혹은 적응증의 문제로 수술적 치료가 불 가능한 경우 국소 치료 및 전신 치료의 병합을 통한 다 학제적 접근으로 간세포암종을 조절하여 간기능의 보 존이라는 진행성 간세포암종 치료의 궁극적 목표 성취 를 통해 생존 연장의 가능성을 기대할 수 있을 것으로 생각되며 이에 대한 추가 연구가 필요하다고 하겠다.

\section{Conflicts of Interest}

The authors have no conflicts to disclose. 


\section{REFERENCES}

1. Ikenaga N, Chijiiwa K, Otani K, et al. Clinicopathologic characteristics of hepatocellular carcinoma with bile duct invasion. J Gastrointest Surg 2009;13(3):492-497.

2. Esaki M, Shimada K, Sano T, et al. Surgical results for hepatocellular carcinoma with bile duct invasion: A clinicopathologic comparison between macroscopic and microscopic tumor thrombus. J Surg Oncol 2005;90:226-232.

3. Moon DB, Hwang S, Wang HJ, et al. Surgical outcomes of hepatocelluar carcinoma with bile duct tumor thrombus: A Korean multicenter study. World J Surg 2013;37:443-451.

4. Yu XH, Xu LB, Liu C, et al. Clinicopathological characteristics of 20 cases of hepatocellluar carcinoma with bile duct thrombi. Dig Dis Sci. 2011;56:252-259.

5. Lai EH, Lau WY. Hepatocellular carcinoma presenting with obstructive jaundice. ANZ J Surg 2006;76:631-636.

6. Kitagawa K, Yamakado K, Nakatsuka A, et al. Selective transcatheter hepatic arterial chemoembolization for hemobilia from hepatocellular carcinoma: report of three cases. J Vasc Interv Radiol 1999;10:1357-1360.

7. Kang JK, Kim MS, Chol CK, et al. Stereotactic body radiation therapy for inoperable hepatocellular carcinoma as a local salvage treatment after incomplete transarterial chemoembolization. Cancer 2012;118:5424-5431. 